\title{
Preparing logistics for the age of volatility
}

\author{
Peter Klaus
}

Published online: 24 September 2011

(C) Springer-Verlag 2011

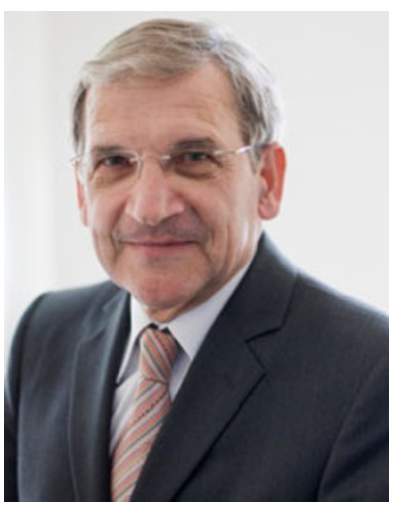

Worldwide logistics activities have been growing again in 2010: The 22nd "Annual State of Logistics Report" for the United States, issued by the Council of Supply Chain Management Professionals (CSCMP) and Penske Logistics in June of this year, says that US national logistics expenditures were $\$ 1.21$ trillion, up about $10.4 \%$ from the recession year 2009. This figure, however, is still about $\$ 180$ bill below the 2007 level - the peak year so far, since reporting started. In October, the Nuernberg Fraunhofer SCS institute, German "Bundesvereinigung Logistik (BVL)" and DVV Media will publish their annual report on the logistics markets of Europe: The figure for Germany's national logistics spending will be at about $€ 210$ bill. (i.e., about $\$ 250$ bill at an assumed "real" exchange rate of $\$ 1,20 / €)$. This is $5 \%$ above the recession year level of 2009. The corresponding figures for the "EU 29" (i.e., the consolidated logistics expenditures of the 27 current members of the European Community, plus Norway and Switzerland) will be $€ 995$ bill., about $\$ 1.19$ trillion, respectively.

Until just two, three months ago, most observers shared the expectation that 2011 will be the second year of a strong recovery from the 2008/2009 recession in most countries and logistics markets. Logistics activity and spending levels for the full year 2011 would reach or even exceed pre-recession volumes. But now, at the end of the third quarter of 2011, anxieties regarding the European "debt" crisis, US concerns of a "second dip" in jobs and

P. Klaus $(\square)$

University of Erlangen-Nürnberg, Nuremberg, Germany

e-mail: Peter.Klaus@wiso.uni-erlangen.de

business activity, and continuing unrest in the Middle East, seem to turn expectations about the growth of logistics sharply downward, again.

When the McKinsey consulting company extended a "welcome to a volatile world" on the title of a recent study, this may have been more than a catchy reference to the ups and downs of the 2008 to 2010 period, which the logistics industries experienced-like many other sectors of the economy. The figures and expectations quoted above may mean that logistics should prepare for a long period of volatility with respect to the quantitative and qualitative demands the industry and the field will have to meet. They suggest the possibility of an end to unlimited growth prospects for logistics, at least as we understood it in the past.

To continue to be relevant to the decision makers and business actors, the community of logistics researchers may have to add the management of "volatility" to their set of high-priority issues-beyond supply chain collaboration and security, and beyond sustainability, which dominated the agendas during the past decade. One obvious response may be to review and reconsider academic contributions to issues of disruptive change, of flexibility and "meta-stability", which were made during past periods of heightened environmental turbulence and uncertainty: What might be the consequence of considering "organizational tents instead of organizational palaces" to the architects of big, global logistics organizations? ... of "loose coupled" instead of tightly, end-to-end integrated supply chains? ... of "systems adaptability" as a substitute to forecasting the unknowable?

We think that logistics research can be enriched in many academically demanding and practically relevant ways, if we accept the challenge of an upcoming age of volatility. As editors of this journal, we invite authors 
to submit their interpretations and responses to this challenge!

In this issue of Logistics Research, we offer a variety of interesting research contributions: Bretzke provides a critique and suggestions for a broader discussion of solutions to a more sustainable future of logistics. Gong, Strang, and Li each offers new approaches to the solution of important issues in logistics operations on the basis of quantitative methods. And Brandenburg/Seuring present the findings from a study on the impact of supply chain management on company value.

Enjoy the reading!

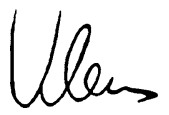

Peter Klaus, Editor-in-Chief LOGISTICS RESEARCH September 2011 